\title{
Phosphorous as the major yield limiting nutrient for maize in the river basin areas of western Nepal
}

\author{
${ }^{1}$ Bhanu Bhakta Pokharel*, ${ }^{2}$ Shashi Ram Sharma, ${ }^{2}$ Gam Bahadur Pun \\ and ${ }^{2}$ Naina Singh Chhetri \\ ${ }^{1}$ Hill Crops Research Program, Kabre, Dolakha \\ ${ }^{2}$ Agricultural Research Station, Dasharathpur, Surkhet \\ *Corresponding author email: bhanu.pokharel@gmail.com
}

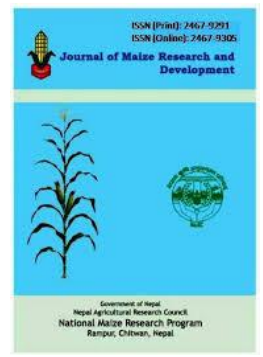

Received: September 2016; Revised: October 2016; Accepted: November 2016

\begin{abstract}
Maize is a heavy feeder crop but not always higher quantity of chemical fertilizers leads for higher grain yield. Objective of the study was to identify the major yield limiting macro nutrient for maize in the river basis areas. Field experiments were conducted at four locations viz. Dasharathpur, Ramghat, Mehelkuna, and Gumi VDCs of Surkhet district, under research command areas of Agriculture Research Station, Surkhet. Different doses of nitrogen, phosphorous and potassium fertilizers were applied. Planting was done in the summer season of 2010 and 2011. All field experiments were laid out in randomized complete block designs with three replications at each site and year. Deuti variety of maize was used in the experiment. Days to tasseling, silking, and physiological maturity due to fertilizer application were found significant. One week earlier silking, tasseling, and physiological maturity was observed due to use of 100:100 $\mathrm{kg} \mathrm{ha}^{-1}$ nitrogen and phosphorous as compared to the most late maturity with application of $100 \mathrm{~kg}$ nitrogen $\mathrm{ha}^{-1}$. The highest grain yield $\left(6802 \mathrm{~kg} \mathrm{ha}^{-1}\right)$ was found with application of 100:100 kg nitrogen and phosphorous ha ${ }^{-1}$ and the lowest grain yield (4174 $\mathrm{kg} \mathrm{ha}$ ${ }^{1}$ ) was found with the normal recommended fertilizer dose. Phosphorous was observed as the major yield limiting factor in this study.
\end{abstract}

Keywords: Grain yield, maize, phosphorous, river basin, western Nepal

Correct citation: Pokhrel, B.B., Sharma, S.R., Pun, G.B., \& Chhetri, N.S. (2016). Phosphorous as the major yield limiting nutrient for maize in the river basin areas of western Nepal. Journal of Maize Research and Development, 2(1), 100-108, doi: http://dx.doi.org/10.3126/jmrd.v2i1.16220

\section{INTRODUCTION}

Farmers are gradually shifting towards commercial cultivation and started to grow improved varieties and/or hybrids of maize in Terai as well as hilly regions of Nepal (KC et al., 2015). The cultivation of improved and hybrids in intensive cropping systems increased nutrients demand (Shrestha et al., 2015). Maize is heavy feeder crop for which locally available nutrients source mostly farmyard manures, compost and biologically fixed nitrogen are not sufficient to 
fulfill the demands of nutrient. The soil fertility decline in the hills increases due to reduction in the organic matter content where nitrogen is the major nutrient which is gradually diminishing in soils of Nepal (Tripathi \& Shrestha, 2001). Chemical fertilizers play a significant role in yield increment however, increased amount of fertilizers not always contribute to increase maize yield (Amujoyegbe et al., 2007). The availability of soil moisture enhances the efficacy of these nutrients uptake (Purdue University, 2012); effect is significantly higher during rainy season maize in our context rather than winter season as we do not have assured irrigation facility. Phosphorous is required for seed formation. It enhances water use efficiency and hastens crop maturity. This nutrient play important role in photosynthesis, cell division, energy transfer, root growth, cell enlargement, root formation (Roberts, 2004). In the soil Potassium (K) is not readily available; it is involved in the structural component of soil minerals. Therefore, the amount of $\mathrm{K}$ supplied by soils varies, which lead to variation in the amount of $\mathrm{K}$ fertilizer applications across soil types (Belay et al., 2002). Potassium is one of 12 nutrients which is necessary for normal corn growth and development. Basically, $\mathrm{K}$ is required for the movement of water, nutrients, and carbohydrates within the plant. It enhances early growth, increases protein production, and improves the water use efficiency and resistance to diseases and insects (Brady $\&$ Weil, 2014). The optimal yield cannot be received if chemical fertilizers are not scheduled and applied at proper dose for accelerated uptake by the plants (Roberts et al., 2004). The actual amount of each nutrient needed depends on the initial soil test level, soil texture, clay minerals, and organic matter level. The objective of our study was to identify the major yield limiting nutrient in the river basin condition of research command areas of Agriculture Research Station (ARS), Surkhet.

\section{Testing sites}

\section{MATERIALS AND METHODS}

Agriculture Research Station (ARS), Surkhet is situated at $28^{0} 30^{\prime}$ Northern latitude, $81^{\circ} 47^{\prime}$ 'Eastern longitude, and 480 meter elevation from the sea level (NARC, 2014). The station is $26 \mathrm{~km}$ southeast from the district headquarter of Surkhet, Birendranagar. Field experiments were conducted at four locations of research command areas of Agriculture Research Station (ARS), situated at the river basin surroundings of the Bheri river of Surkhet district. All the research sites had a moderate climate where winter temperatures dropped to $5^{\circ} \mathrm{C}$ and in summer it raised up to $38^{\circ} \mathrm{C}$ (NARC, 2014). All the research sites have the subtropical hot humid climate. All the testing sites have similar climatic conditions to the ARS Surkhet because they are in the almost similar altitude and not far than 7 kilometers from the research station. The weather condition was as usual during the maize growing season for both the years at all the locations. Based on the soil analysis report from Soil Science Division, Khumaltar, initial nutritional status of different available major nutrients, soil organic matter, and $\mathrm{pH}$ of the experimental sites were $\mathrm{N}$ (0.11 to $0.178 \%), \mathrm{P}_{2} \mathrm{O}_{5}$ (14-17 parts per million, ppm) $\mathrm{K}_{2} \mathrm{O}$ (52-83 ppm), organic matter content (2.8-3.2\%). Similarly, the soil was moderately acidic in reaction (pH: 5.32 to 5.81).

\section{Maize variety}

Deuti, a full season open pollinated variety of maize was selected for the study. Deuti was introduced in Nepal in 1999/2000 from the International Center for Wheat and Maize Improvement (CIMMYT) in the name of ZM-621. This variety was developed at Zimbabwe 
under CIMMYT regional research program for maize in the dry areas. This variety was tested for more than six years in Nepal at different growing environments under different trials and recommended for general cultivation for mid hills, Terai, and inner Terai conditions of Nepal.

\section{Field experiment and data collection}

Field experiments were laid out in four locations viz. Dasharathpur, Mehelkuna, Gumi, and Ramghat villages of Surkhet district during the rainy season of 2010 and 2011. Six different combinations of N, P, and K fertilizers were tested which is given as below;

T-1: $\quad$ Farmers'practice $\left(20 \mathrm{~kg} \mathrm{~N}+10\right.$ ton FYM ha $\left.{ }^{-1}\right)$

T-2: $\quad 100 \mathrm{~kg} \mathrm{~N} \mathrm{ha}^{-1}$

T-3: $100: 100 \mathrm{~kg} \mathrm{NP} \mathrm{ha}^{-1}$

T-4: $100: 100: 100 \mathrm{~kg} \mathrm{NPK} \mathrm{ha}^{-1}$

T-5: $\quad$ 100:100:100 $\mathrm{kg} \mathrm{NPK} \mathrm{ha}^{-1}+5$-ton lime ha-1

T-6: Recommended dose (120:60:40 kg NPK ha ${ }^{-1}$ )

Randomized complete block (RCB) design with three replications at each site was followed for each year. At all the locations, each plot size was 13.5 meter square. Width of the plot was 4.5 meter i.e. six rows with $75 \mathrm{~cm}$ row to row distance and $25 \mathrm{~cm}$ plant to plant distance. The length of the plot was 3 meter. Planting was done on 12, 14, 16 and 18 June, 2010 and 11, 13, 15 and 17 June, 2011 at Dasharathpur, Ramghat, Mahelkuna and Gumi village development committee (VDC), respectively. Sources of phosphorous was single super phosphate (16\% phosphorous), source of potash was murate of potash (60\% potash), and source of nitrogen was urea (45 \% nitrogen). All amount of phosphorous, potash, and one third amount of nitrogen was applied at the time of sowing. Remaining tow third of nitrogen, $50 \%$ was used at knee high stage and another 50\% at tasseling/silking period, respectively. Weeding was done manually at 30 DAS and earthing up at 50 DAS. Rest of other cultural practices was done as per recommendation of National maize Research Program (NMRP), Rampur, Chitwan. Parameters like plant and ear height, flowering, physiological maturity, and grain yield were evaluated. Grain yield was estimated using formula adopted by Carangal et al. (1971) and Shrestha et al.( 2015) by adjusting the grain moisture at $15 \%$ and converted to the grain yield kg per hectare. Data were analyzed by using CROP-STAT computer program applying 5\% level of significance.

\section{RESULTS AND DISCUSSION}

\section{Days to tasseling, silking, and physiological maturity}

Statistically, significant difference $(\mathrm{P}<0.001)$ was observed for days to tasseling and days to silking due to applications of different doses of chemical fertilizers. The earliest tasseling (55 days) and silking (60 DAS) was found with the application of 100:100 kg N and $\mathrm{P} \mathrm{ha}^{-1}$, respectively. Likewise, the most late tasseling (61 days) and silking (68 days) was observed with the application of $100 \mathrm{~kg} \mathrm{~N} \mathrm{ha}^{-1}$. Phosphorous is the precursor for flowering and it plays a significant role for shortening the maturity period (Belay et al., 2002). Nitrogen is one of the basic structural elements and plays significant role in construction of chlorophyll (Brady \& Weil, 
2014), therefore nitrogen is responsible for vegetative growth as well. Effect of nitrogen and phosphorous on vegetative growth and maturity was clearly observed in this study and consequently, phosphorous shortened the duration for flowering whereas the nitrogen delayed it. A detail of the research result is presented in Table 1.

Table1. Response of Deuti variety of maize to tasseling and silking days as influenced by different doses of $\mathrm{N}, \mathrm{P}$, and $\mathrm{K}$ during the summer of 2010 and 2011.

\begin{tabular}{|c|c|c|c|c|c|c|c|c|c|c|c|}
\hline \multirow[t]{3}{*}{$\mathrm{SN}$} & \multirow[t]{3}{*}{ Treatment } & \multicolumn{10}{|c|}{ Days to $50 \%$ flowering } \\
\hline & & \multicolumn{4}{|c|}{ Tasseling } & \multirow[b]{2}{*}{ Av. } & \multicolumn{4}{|c|}{ Silking } & \multirow[b]{2}{*}{$\mathrm{Av}$} \\
\hline & & $\begin{array}{l}\overline{D^{\prime}} \\
\text { Pur }\end{array}$ & $\begin{array}{l}\text { Ram } \\
\text { ghat }\end{array}$ & $\begin{array}{l}\text { Mahel } \\
\text { kuna }\end{array}$ & Gumi & & $\begin{array}{l}\overline{D^{\prime}} \\
\text { pur }\end{array}$ & $\begin{array}{l}\text { Ram } \\
\text { ghat }\end{array}$ & $\begin{array}{l}\text { Mahel } \\
\text { kuna }\end{array}$ & Gumi & \\
\hline 1 & $\begin{array}{l}\text { Farmers'practice } \\
(20 \mathrm{~kg} \mathrm{~N}+10 \text { ton } \\
\left.\text { FYM ha }^{-1}\right)\end{array}$ & 58 & 55 & 59 & 60 & 58 & 65 & 60 & 64 & 64 & 63 \\
\hline 2 & $100 \mathrm{~kg} \mathrm{~N} \mathrm{ha}^{-1}$ & 65 & 58 & 61 & 61 & 61 & 72 & 64 & 66 & 68 & 68 \\
\hline 3 & $100: 100 \mathrm{~kg} \mathrm{NP} \mathrm{ha}^{-1}$ & 56 & 51 & 57 & 57 & 55 & 61 & 56 & 62 & 62 & 60 \\
\hline 4 & $\begin{array}{l}\text { 100:100:100 kg } \\
\text { NPK ha }^{-1}\end{array}$ & 61 & 55 & 57 & 58 & 56 & 65 & 59 & 61 & 62 & 62 \\
\hline 5 & $\begin{array}{l}\text { 100:100:100 kg } \\
\text { NPK ha-1 }+5 \text {-ton } \\
\text { lime ha } \mathrm{ha}^{-1}\end{array}$ & 58 & 54 & 59 & 59 & 58 & 62 & 58 & 63 & 63 & 62 \\
\hline 6 & $\begin{array}{l}\text { Recommended dose } \\
(120: 60: 40 \mathrm{~kg} \text { NPK } \\
\left.\mathrm{ha}^{-1}\right)\end{array}$ & 63 & 55 & 59 & 62 & 60 & 68 & 60 & 64 & 66 & 65 \\
\hline & Average & 60 & 55 & 59 & 60 & 58 & 66 & 60 & 63 & 64 & 63 \\
\hline & $\mathrm{CV} \%$ & & & 3.28 & & & & & 3.30 & & \\
\hline & $\mathrm{P}$ value (Location) & & & $<0.01$ & & & & & $<0.01$ & & \\
\hline & $P$ value (Treatmenets) & & & $<0.01$ & & & & & $<0.01$ & & \\
\hline & $\mathrm{LSD}_{0.05}$ & & & 2.99 & & & & & 2.94 & & \\
\hline
\end{tabular}

Note: $\mathrm{P}_{\mathrm{L}}-\mathrm{P}$ value for location, $\mathrm{P}_{\mathrm{T}}-\mathrm{P}$ value for different treatments, D'pur - Dasharathpur, Av. - Average

Similarly, significant difference $(\mathrm{P}<0.001)$ was found for physiological maturity due to application of different doses of chemical fertilizers. For days to physiological maturity too, application of 100:100 kg ha ${ }^{-1} \mathrm{~N}$ and $\mathrm{P}$ attained the earliest maturity (107 DAS). The most late (114 DAS) physiological maturity was observed with $100 \mathrm{~kg} \mathrm{~N} \mathrm{ha}^{-1}$. The difference in maturity was found 7 days between these two treatment combinations. The causes behind late in maturity would the same as in the case of days to flowering where nitrogen helped delay in maturity and phosphorous for earliness in maturity as mentioned by Baley et al.(2002). A graphical representation of the result is presented in Figure 1.

\section{Plant and Ear height}

The different levels of fertilizers application significantly affected the plant height. The tallest plant height $(224 \mathrm{~cm})$ was measured with $100 \mathrm{~kg} \mathrm{~N} \mathrm{ha}^{-1}$. There was no statistical significant difference for rest of the treatment combinations for plant height. Similarly, ear height was also found significantly taller $(121 \mathrm{~cm})$ with the application of only $100 \mathrm{~kg} \mathrm{~N} \mathrm{ha}^{-1}$. The taller ear and plant height might be due to increment in dry matter accumulation as $\mathrm{N}$ contributed more 
Journal of Maize Research and Development (2016) 2 (1): 100-108

ISSN: 2467-9291 (Print), 2467-9305 (Online)

DOI: http://dx.doi.org/10.3126/jmrd.v2i1.16220

for vegetative growth as mentioned by Roberts et al. (2004). The result showed a significant effect of $\mathrm{N}$ on plant and ear height. A detail of research result is presented in table 2.

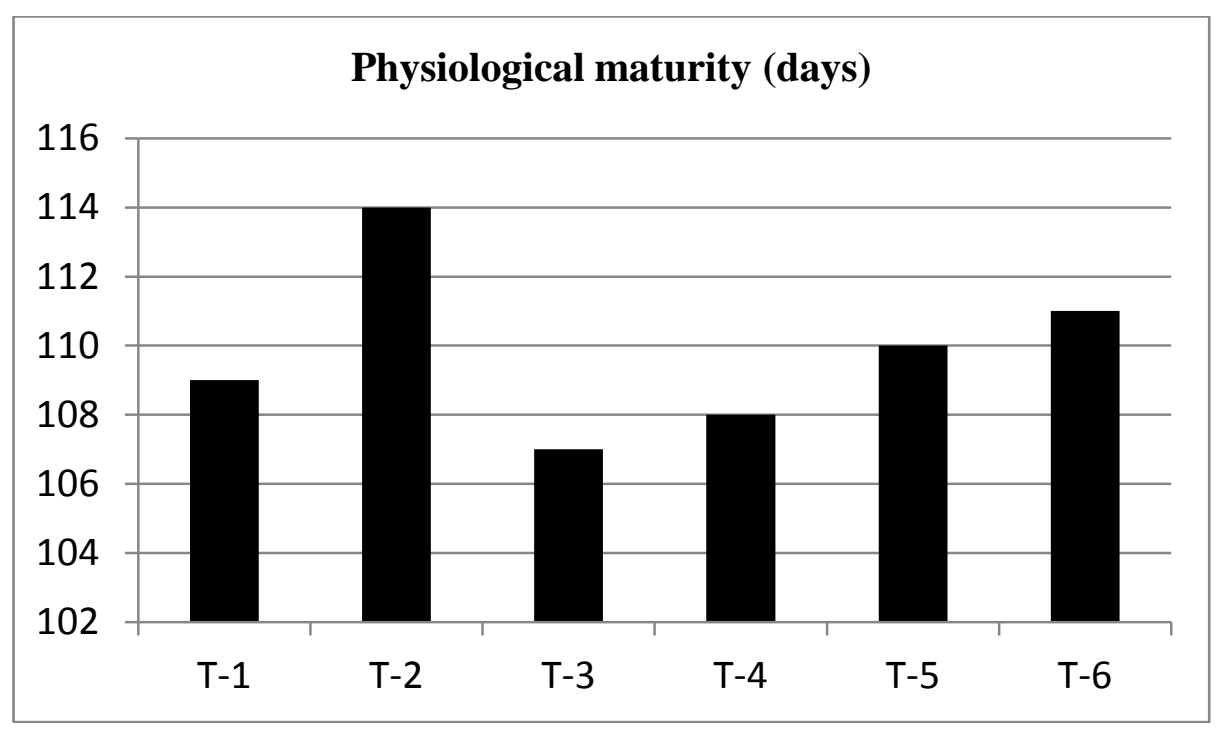

Figure 1. Physiological maturity (days) as affected by application of different fertilizer dose in the river basin areas of Surkhet district during the rainy season of 2010 and 2011

Table2. Plant and ear height of Deuti maize variety due to application of different major nutrients during the rainy season of 2010 and 2011.

\begin{tabular}{|c|c|c|c|c|c|c|c|c|c|c|c|}
\hline \multirow{3}{*}{\multicolumn{2}{|c|}{$\begin{array}{ll}\text { SN } & \text { Treatments }\end{array}$}} & \multicolumn{10}{|c|}{ Height $(\mathrm{cm})$} \\
\hline & & \multicolumn{4}{|c|}{ Ear height } & \multicolumn{6}{|c|}{ Plant height } \\
\hline & & $\begin{array}{l}\text { D' } \\
\text { pur }\end{array}$ & $\begin{array}{l}\text { Ram } \\
\text { ghat }\end{array}$ & $\begin{array}{c}\text { Mahel } \\
\text { kuna }\end{array}$ & Gumi & Av. & $\begin{array}{l}\text { D' } \\
\text { pur }\end{array}$ & $\begin{array}{l}\text { Ram } \\
\text { ghat }\end{array}$ & $\begin{array}{c}\text { Mahel } \\
\text { kuna }\end{array}$ & Gulmi & Av. \\
\hline 1 & $\begin{array}{l}\text { Farmers' } \\
\text { practice }(20 \mathrm{~kg} \mathrm{~N}+ \\
\left.10 \text { ton FYM ha }{ }^{-1}\right)\end{array}$ & 95 & 122 & 124 & 106 & 112 & 182 & 221 & 226 & 208 & 209 \\
\hline 2 & $100 \mathrm{~kg} \mathrm{~N} \mathrm{ha}^{-1}$ & 125 & 120 & 125 & 121 & 123 & 222 & 229 & 227 & 216 & 224 \\
\hline 3 & $100: 100 \mathrm{~kg} \mathrm{~N}: \mathrm{P} \mathrm{ha}^{-1}$ & 102 & 104 & 105 & 117 & 107 & 196 & 207 & 198 & 217 & 205 \\
\hline 4 & $\begin{array}{l}\text { 100:100:100 } \\
\mathrm{kg} \mathrm{NPK} \mathrm{ha}^{-1}\end{array}$ & 109 & 110 & 105 & 103 & 107 & 209 & 207 & 195 & 201 & 203 \\
\hline 5 & $\begin{array}{l}\text { 100:100:100 } \\
\text { kg NPK ha- } \\
+5 \text {-ton lime ha }\end{array}$ & 101 & 103 & 99 & 98 & 100 & 201 & 193 & 199 & 198 & 198 \\
\hline 6 & $\begin{array}{l}\text { Recommended } \\
\text { dose }(120: 60: 40 \mathrm{~kg} \\
\left.\text { NPK } \mathrm{ha}^{-1}\right)\end{array}$ & 106 & 113 & 112 & 108 & 110 & 212 & 219 & 210 & 198 & 210 \\
\hline & Average & 106 & 112 & & 109 & 110 & 204 & 213 & 209 & 20 & \\
\hline & $\mathrm{CV} \%$ & 6.95 & & & & & 11.34 & & & & \\
\hline & $\mathrm{P}$ value (Location) & $<0.01$ & & & & & $<0.01$ & & & & \\
\hline & $\mathrm{P}$ value ${ }_{\text {Treatments }}$ & $<0.01$ & & & & & $<0.01$ & & & & \\
\hline & $\mathrm{LSD}_{0.05}$ & 16.29 & & & & & 15.47 & & & & \\
\hline
\end{tabular}

D’pur - Dasharathpur, Av. - Average 


\section{Grain Yield}

Statistically, significant $(\mathrm{P}<0.001)$ result was found for grain yield due to application of different rates of major chemical fertilizers. The highest grain yield $\left(6802 \mathrm{ha}^{-1}\right)$ was produced with the application of 100:100 kg NP ha ${ }^{-1}$. While, the lowest grain yield $\left(4174 \mathrm{ha}^{-1}\right)$ was observed with the farmers' practice i.e. application of $20 \mathrm{~kg} \mathrm{~N} \mathrm{ha}^{-1}$ at knee high stage and 10 ton FYM ha ${ }^{-1}$ at the time of maize seed sowing. $63 \%$ more yield was found with the application of 100:100 kg NP ha ${ }^{-1}$ as compared to farmers' practice. Likewise, 52\% more yield was found with the application of 100:100:100 $\mathrm{kg} \mathrm{NPK} \mathrm{ha}^{-1}$ followed by $50 \%$ more yield with 100:100:100 kg NPK ha ${ }^{-1}+5$ ton $\mathrm{ha}^{-1}, 49 \%$ more yield with recommended dose and $43 \%$ more yield with $100 \mathrm{~kg}$ $\mathrm{N} \mathrm{ha}^{-1}$, respectively. A summarized result is presented in table 3. Phosphorous was observed one of the principle plant nutrients for maize yield in this study. It is involved in many physiological processes like assimilate transport, photosynthesis, and enzyme activation that have direct consequences on crop productivity (Belay et al., 2002) that the role of phosphorous and potassium for maize growth and development was crucial. Similar result was also found by Pokharel et al., (2004) in an experiment conducted under mid hill environments of Dailekh district of Nepal. The lower yield in farmers' practice might be due to lower minerals supplement by the FYM. The compost fertilizer contains around 0.5-0.7 percent $\mathrm{N}, 0.4-0.75$ percent $\mathrm{P}$, and 0.2-0.55 percent K (Brady \& Weil, 2014). In this study, it is found that the role of phosphorous and nitrogen was noticeable while potash did not play a significant role for higher grain yield. It may be due to the presence of medium amount of potash in the soil. The soil analysis report also showed a medium concentration of potash. Phosphorous was the major chemical fertilizer that played a significant role for higher productivity of maize in the river basin areas of the study areas. There was no significant effect of lime for grain yield in this study. Summary of research result is resented in Table 3 .

Table 3. Response of Deuti maize variety for grain yield as influenced by different chemical fertilizer application during the rainy season of 2010 and 2011 under river basin areas.

\begin{tabular}{|c|c|c|c|c|c|c|c|c|}
\hline \multirow[b]{2}{*}{$\mathrm{SN}$} & \multirow[b]{2}{*}{ Treatments } & \multicolumn{4}{|c|}{ Grain yield $\left(\mathrm{kg} \mathrm{ha}^{-1}\right)$} & \multirow[t]{2}{*}{ Av. } & \multirow{2}{*}{$\begin{array}{c}\text { YIOFP } \\
\left(\mathrm{kg} \mathrm{ha}^{-1}\right)\end{array}$} & \multirow{2}{*}{$\begin{array}{c}\text { YIOFP } \\
(\%)\end{array}$} \\
\hline & & D’ pur & $\begin{array}{l}\text { Ram } \\
\text { ghat }\end{array}$ & $\begin{array}{c}\text { Mahel } \\
\text { kuna }\end{array}$ & Gumi & & & \\
\hline 1 & $\begin{array}{l}\text { Farmers' practice }\left(20 \mathrm{~kg}^{-1}\right. \\
\left.\mathrm{N} \mathrm{ha}^{-1}+10 \text { ton } \mathrm{FYM} \mathrm{ha}{ }^{-1}\right)\end{array}$ & 3125 & 4538 & 5362 & 3672 & 4174 & 0 & 0 \\
\hline 2 & $100 \mathrm{~kg} \mathrm{~N} \mathrm{ha}^{-1}$ & 3494 & 6353 & 7725 & 6297 & 5967 & 1793 & 43.0 \\
\hline 3 & 100:100 kg NP ha-1 & 5477 & 7801 & 7129 & 6803 & 6802 & 2628 & 63.0 \\
\hline 4 & 100:100:100 kg NPK ha-1 & 5446 & 7624 & 6832 & 5447 & 6337 & 2163 & 51.8 \\
\hline 5 & $\begin{array}{l}\text { 100:100:100 kg NPK ha-1 } \\
\text { + 5-ton lime ha- }\end{array}$ & 6265 & 6148 & 7086 & 5504 & 6251 & 2077 & 49.8 \\
\hline 6 & $\begin{array}{l}\text { Recommended dose } \\
\left(120: 60: 40 \mathrm{~kg}^{-1} \mathrm{~h} \mathrm{ha}^{-1}\right)\end{array}$ & 5444 & 6358 & 6254 & 6873 & 6232 & 2058 & 49.3 \\
\hline & Average & 4875 & 6470 & 6731 & 5766 & 5961 & - & - \\
\hline & $\begin{array}{l}\mathrm{CV} \% \\
\mathrm{P} \text { value (Location) } \\
\mathrm{P} \text { value (Treatments) } \\
\text { LSD }_{0.05}\end{array}$ & & & $\begin{array}{l}13.17 \\
>0.05 \\
<0.01 \\
1926\end{array}$ & & & - & - \\
\hline
\end{tabular}

D'pur - Dasharathpur, Av. - Average 
Journal of Maize Research and Development (2016) 2 (1): 100-108

ISSN: 2467-9291 (Print), 2467-9305 (Online)

DOI: http://dx.doi.org/10.3126/jmrd.v2i1.16220

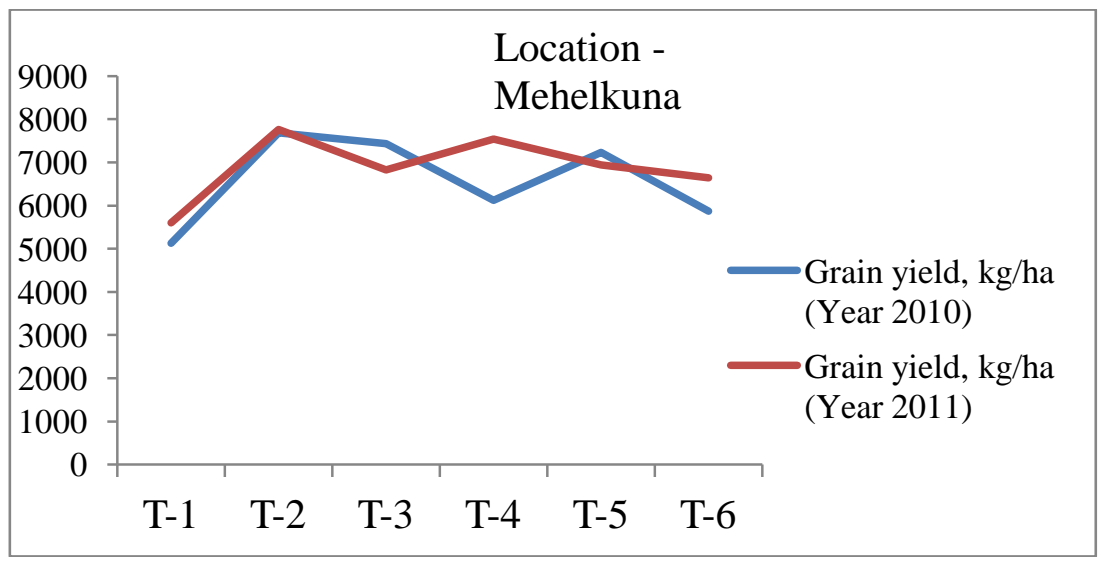

Figure 2. Grain yield $\left(\mathrm{kg} \mathrm{ha}^{-1}\right)$ as influenced by different fertilizer doses of NPK at Mahelkuna of Surkhet district

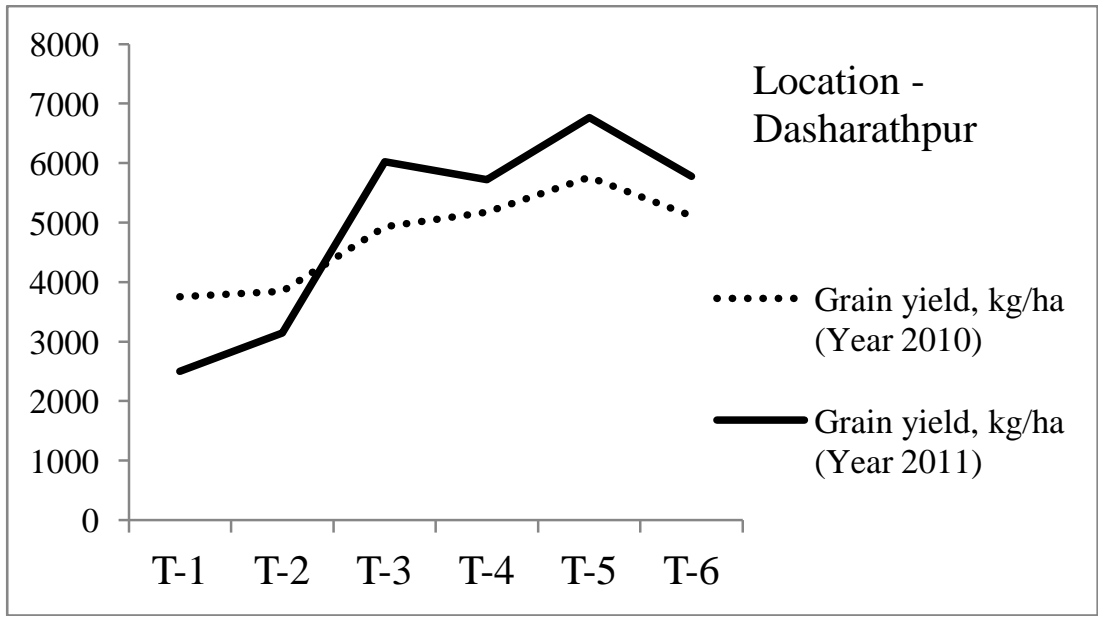

Figure 3. Response of different NPK fertilizer doses on grain yield ( $\left.\mathrm{kg} \mathrm{ha}^{-1}\right)$ of maize for two consecutive years (2010 and 2011) at Dasharathpur, Surkhet

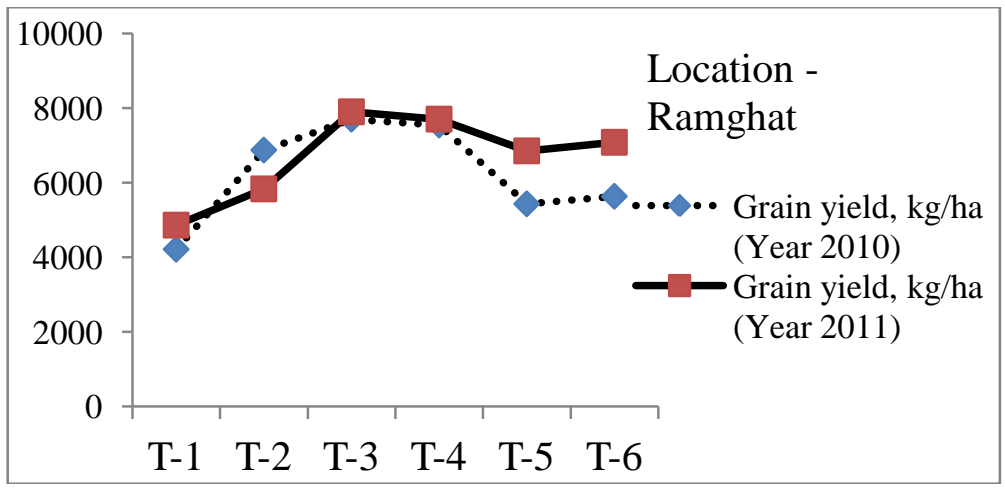

Figure 4. Response of different NPK fertilizer doses on grain yield $\left(\mathrm{kg} \mathrm{ha}^{-1}\right)$ of maize for two consecutive years (2010 and 2011) at Ramghat, Surkhet 


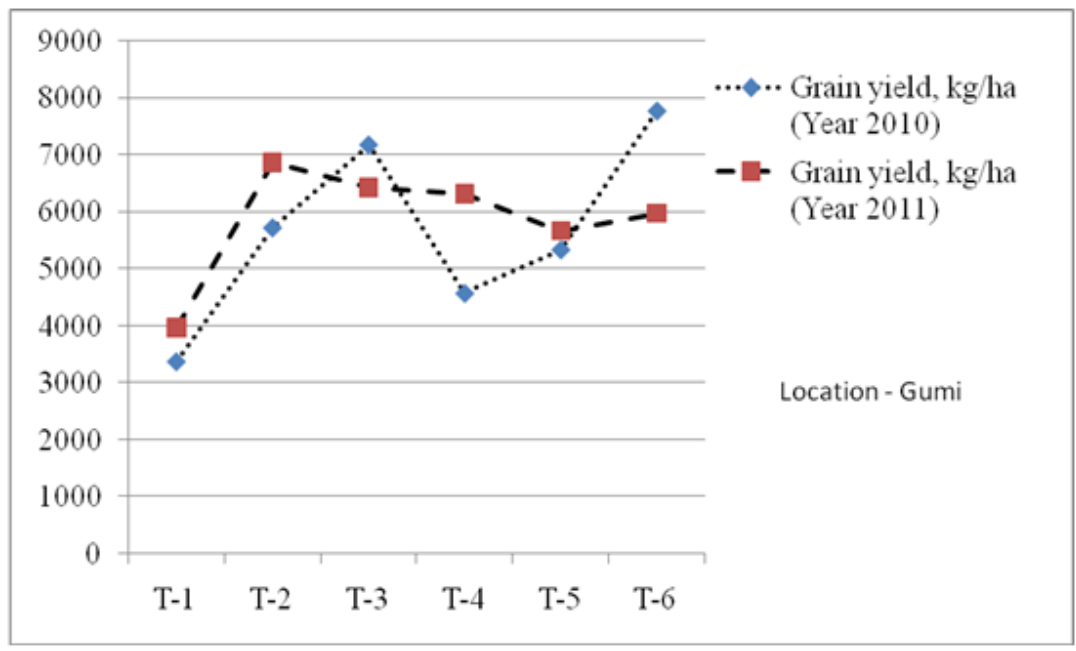

Figure 5. Response of different NPK fertilizer doses on grain yield ( $\left.\mathrm{kg} \mathrm{ha}^{-1}\right)$ of maize for two consecutive years (2010 and 2011) at Gumi, Surkhet

\section{CONCLUSION}

Maize with 100:100 kg NP ha ${ }^{-1}$ attained earliest maturity. The role of phosphorous in early maturity was clearly observed in this experiment. The difference in maturity was found 7 days between these two extremes. The highest grain yield $\left(6802 \mathrm{~kg} \mathrm{ha}^{-1}\right)$ was found with 100:100 $\mathrm{kg} \mathrm{NP} \mathrm{ha}{ }^{-1}$ and the lowest grain yield $\left(4174 \mathrm{~kg} \mathrm{ha}^{-1}\right)$ was found with farmers practice i.e. application of $20 \mathrm{~kg} \mathrm{~N} \mathrm{ha}^{-1}$ at knee high stage and 10 ton FYM at sowing time. The role of potash on grain yield was found negligible in this study. Phosphorous was found as the major nutrient that limits yield in these regions. The role of lime for grain yield was also found minimal.

\section{ACKNOWLEDGEMENTS}

The authors are indebted with the farmers of Dasharathpur, Gumi, Mehelkuna, and Ramghat VDCs of Surkhet district who directly or indirectly helped to accomplish the field research works. Their sincere thanks go to late Mr. Jhalak Dhakal whose help for this work is innumerable. They also gratefully acknowledge the contributions made by other technical as well as administrative staffs of ARS, Surkhet who helped in accomplishing this research work successfully. Authors also thank NARC for providing funds for this study.

\section{REFERENCES}

ABPSD. (2015). Agri-business Promotion andand Statistics Division. Statistical Information on Nepalese Agriculture. Ministry for Agriculture and Cooperatives, Singadarbar, Kathmandu, Nepal. 
Amujoyegbe, B. J., Opabode J. T., \& Olayinka, A. (2007). Effect of organic and inorganic fertilizer on yield and chlorophyll content of maize (Zea mays L.) and sorghum (Sorghum bicolour (L.) Moench). African Journal of Biotechnology, 6 (16), 1869-1873.

Belay, A., Claassens, A., \& Wehner, F (2002). Effect of direct nitrogen, potassium and residual phosphorus fertilizers on soil chemical properties, microbial components and maize yield under long-term crop rotation. Journal of biology and fertility of soils. 35, 420-427.

Brady, N.C., \& Weil, R.R., (2014). The Nature and Properties of Soils, (14 ${ }^{\text {th }}$ ed., pp. 567, 615, and 671). New Delhi, India: Pearson Education.

Carangal, V.R., Ali, S.M., Koble, A.F., \& Rinke, E.H. (1971). Comparison of S1 with testcross evaluation for recurrent selection in maize. Crop Science, 11, 658-661. doi:10.1007/s00374-002-0489-x

KC, G., Karki, T.B., Shrestha, J., \& Acchami, B.B. (2015). Status and prospects of maize research in Nepal. Journal of Maize Research and Development, 1(1):1-9.

NARC. (2014). Nepal Agricultural Research Council, Annual Report of Agriculture Research Station, Dasharathpur, Surkhet, Nepal.

Pandey, S.P. (2000). Current soil fertility management, recommendations, constraints and opportunities for maize based cropping systems in the hills of Nepal. In Tripathi, B.P., Rajbhandari, N.P., \&and Ransom, J.K. (eds): Improving soil fertility management for sustainable maize productions. 16-18 August, 2000. Lumle, Kaski, Nepal.

Pokharel B.B., Adhikari, B.N., Koirala, K.B., Gurung, D.B., Poon, T.B., \& Sharma, S.R. (2004). Assessment of the major maize yield limiting nutrients in mid and far western mid hill environments. pp 140-142. In: Sherchan D.P., (eds.) Proceedings of the $24^{\text {th }}$ national summer crops research workshop on maize research and production in Nepal. Organized by NMRP and NARC, 28-30 June 2004, Kathmandu, Nepal.

Roberts R.K., Walters, J.T., Larson, A., English, B.C., \& Howard, D.D. (2004). Effects of disease, nitrogen source, and risk on optional nitrogen fertilization timing in winter wheat production. Agronomy Journal, 96 (3), 792-799.

Shrestha, J., Koirala, K., Katuwal, R., Dhami, N., Pokhrel, B., Ghimire, B., Prasai, H., Paudel, A., Pokhrel, K., \& KC, G. (2015). Performance evaluation of quality protein maize genotypes across various maize production agro ecologies of Nepal. Journal of Maize Research and Development, 1(1), 21-27. doi:http://dx.doi.org/10.3126/jmrd.v1i1.14241

Tripathi, B.P., \& Shrestha, S. (2001). Improved soil fertility management for sustainable maize production workshop group meeting of the hill maize research project. Kathmandu: NARC and CIMMYT. 